\title{
Evaluating Institutional Capability of Nepali Grassroots Organizations for Service Delivery Functions
}

Keshav K. Acharya

\begin{abstract}
Grassroots organizations are well situated to deliver the services and implement the development activities at community level in Nepal. The development of grassroots organizations on the one hand enables the effective service delivery while it enhances community governance system on the other. This study analyses the institutional capability of grassroots level organizations in relation to their service delivery and the study is based on primary and secondary data. One hundred and ten grassroots level organizations were chosen for organizational survey, and three focus group discussions were employed to supplement survey data. The Composite Index (CI) method was employed to analyze the data that shows overall capability of grassroots organizations remained efficient (CI $=0.77)$. Empirical findings indicate that many grassroots organizations were more committed to work as agents of change through institutional norms, rules and values. Nevertheless, some grassroots organizations were facing institutional crises, influenced by socio-economic power structure, and resource paucity. Following the discussion of results, this study recommends governance measure for efficient capability of grassroots organizations.
\end{abstract}


Keywords: Grassroots, organizations, capacity, community governance, service delivery, Nepal

\section{Introduction}

Institutions are both formal and informal structures and mechanisms of social order, which govern society according to certain behavior patterns, formal and informal rules, customs and unique strategies within which individuals and organizations operate to meet societal needs (Hasan, Mitra, \& Ulubasoglu, 2007). North (1993:12) defines "institutions are the rules of the game and organizations are the players". More specifically, institutions are the set of human interactions, and the organizations are the agents of institutional change. For more explicit manner, institutions and organizations are differentiated based on their roles and power functions. The first is concerned to the rules of the game, while latter are the players that consists "groups of individuals bound by common purpose to achieve the objectives of political, economic and social context" (Boliari \& Topyan, 2011, p. 3). Most importantly, organizations' contribution remain to institutionalize of the process, and legitimize of the actions in the state structure and customary practices (Colyvas $\&$ Powell, 2006). Broadly, these processes increase people's selfengagement in collective actions, belongingness and solidarity chain. In the past, communities themselves were more cognizant to institute the number of norms and values that governed intangible institutions like kinship, marriage, inheritance and barter system at community level and controlled by their members (deSouza, 2003). However, the process has been changed in the course of time due to specialized organizations such as cooperatives, and credit unions or more formal institutions. Such formal institutions used to engage in delivering basic services, advocating for social well-being, taking collective initiatives, and generating community belongingness and solidarity (Dongier et al., 2003).

Acharya (2016a) appends that the failure of the market mechanism in the late $1960 \mathrm{~s}$, the state machineries of many nations were inept to reach the communities for delivering of basic services. These created economic vulnerabilities, governance failures and institutional crisis in state service mechanism. Similarly, the emergence of the neo-liberalization in 1970s has focused on privatization, denationalization and deregulation to address 


\section{2| Keshav K. Acharya}

merely reductions in trade barriers, efficient resource allocation, and optimum utilization of commodities and services. Despite the futile of market mechanism and overwhelming interventions of neoliberalization failed to address the issues of structural change of societies, operationalization and delivery of public services, social exclusion, and creating social safety nets for marginalized sections of the communities (Bell \& Cloke, 1989).

Subsequent to address the issues, the third sector of organizations including community associations come to existence with their worthwhile role in policy dialogue and advocacy, service delivery and building community support, and social capital development (Nelson, 2007). O'Toole \& Burdess (2004) illustrate that CBOs are people's institutions as they serve governanceoriented activities, community facilitation actions, and collaboration both within and outside the local community. Examples show that communities are more satisfied through partnering with CBOs in healthcare, education and water supply systems in Pakistan (Acharya, 2016b). In Nigeria, quality services including education, health and sanitation are efficiently delivered by CBOs (Batley, 2006). In South Africa, the involvement ofCBOs in community infrastructure projects reduced costs by half, compared to similar government projects (Dongier, Domelen, et al., 2003). In Bangladesh, CBO leaders hold key positions in local government bodies and are thereby able to serve more effectively in the political and governance system (Baroi \& Rabbani, 2011). In Nepal, only about 46 percent of constructed schemes under central and local government are functional and only 41 percent of projects are effective in the rural areas, whereas the $\mathrm{CBO}$ role in these areas is said to be highly effective, awareness raising and playing a complementary role in basic service delivery (Prasain, 2008).

Following the context, the major strengths of grassroots organizations are to promote community governance, including people's participation, organizational autonomy, maintain transparency and accountability, develop coordination and linkages, and foster greater democracy. In Nepal, the grassroots organizations' has upheld to overcome the poverty and disadvantaged situation, knitting society together at the grass roots and deepening democracy through mobilizing resources, solving problems, and exploring of the common interests. Acharya (2015) illustrates that grassroots organization capacity enhances their potentialities; directs to follow 
the system and process; creates competencies, and responsiveness; and ensures service quality so that grassroots organizations become an integral part of community service system, and contribute in decision making and crisis management system. Following the essence of grassroots organizations as development actors this study assesses to what extent they are capable in delivering community services?

\section{Capability of Grassroots Organizations and Their Roles}

Capability is an asset by which individual's groups, organizations, institutions and societies acquire through training, resources, and environment to perform the functions, solve the problems and achieve the objectives (McPhee \& Bare, 2001). Institutional capability includes continue support to organizations and its components for essential change in knowledge and skill, and procedural methods. Talukder (2004) adds that institutional capability focuses on policy reform, improvements in service delivery, and coordination among the institutional actors that stimulate the individuals, organizations, and societies. In addition, Ostrom (2007) complements that institutional capability assessment is a process of institutional evaluation mainly with the organizational policies, plans, and activities that indicate the institutional competencies, better association, and effective service delivery. Paudel and Thapa (2001) illustrate that capability analysis is a continual process for improving organizational dynamics and service efficiency. It makes correction in the mismanagement of actions, increase organizations' ability and finally supports to the effective programme formulation and implementation. Kindness and Gordon (2001) point out that not only developing countries, but also grassroots organizations are the best vehicles for effective service delivery in developed countries. In the United Kingdom, grassroots organizations engage with basic services such as education, health, water, infrastructure and agriculture and gradually shift towards a longer-term development.

In Nepal, grassroots organizations' engagement and their performance for community based service delivery during the civil war was very much effective and their role was much more appreciative by many developing agencies (UNDP/N, 2009). These indicate grassroots organizations are a new form of governing system which help to democratize the actions for giving opportunity 


\section{4| Keshav K. Acharya}

to the people to participate in governance, strengthen selfgoverning system, create transparency and fair resource distribution mechanism, give clout to local communities for strong voice; and build responsive governance (Uphoff, 1993). Experience from the Rural Credit Program of Bangladesh, Community Forest Program of Nepal and India, and cooperative movement in different countries promise that Grassroots organizations are the most genuine and viable people's organizations, which plays a special role in overcoming poverty and disadvantage, knitting society together at the grass roots and deepening democracy (Chhetri, Joshi, \& Maharjan, 2007).

However, criticism remains that many grassroots organizations have low institutional, human and material capacity to help carry out their envisioned activities. The lack of fairness, equality, accountability, opportunity, choice, participation, mutuality, reciprocity and continuous learning lead to the poor service delivery. Thus, the involvement, functions, and the process of grassroots organizations participation in the policy dialogue have led to the identification of three distinct ideological categories which are involved in the policy debate on development discourse. These are radical, liberal, and transformative notions (Veltmeyer, 2005).

\section{Radical Notion}

In the late $17^{\text {th }}$ century, the radical school was emerged against to malevolence of the state and non- state actors as radical scholars' views that the state and non-state mechanism are steered the conservative religious course, which largely fail to address the people's aspirations (Greenberg, 2001). To grassroots organizations radical scholars argue that they are unskilled, elite captured and work as donors' agent in delivering of basic community services. Their prime attention is on the funding agencies, the economic dimension, and supply-driven-service delivery system (De Wit \& Berner, 2009). Radical notion of the grassroots organizations' action promotes retaining traditional social institutions as they focuses on social hierarchy, and act in parallel with government and create another layer of bureaucracy (Shaktin, 2009). These actions ascertain ineffective government policies, lack of commitment in the implementation of programs, and power attitude of the political and bureaucratic front liners. Veltmeyer (2005) claims that grassroots organizations' inefficiency is not only associated with their inability 
to promote local participation, identify local needs, mobilize local resources, operate tailored projects within strict budgets, and reach the poor, marginal and remote segments of the communities, but also have institutionalized downgraded indigenous governance system.

In this setting, donors' role has also created crisis and a type of colonized mindset in the community. This constructs dependency and destroys self-sustainability and managerial capacity for basic service delivery. Urry (2000) claims that many donor agencies in developing countries offered their assistance in conjunction with grassroots organizations in response to immediate and localized needs, soon after they establish a kind of economic colonialism and, if for some reasons they withheld their resources, the grassroots organizations would collapse. Soderbaum (1992) illustrates that the radical notion is much weak, incomplete, inadequate, and limited chances for community dynamics and people's participation in service delivery mechanism. As a result, conservatism was disapproved by liberal scholars since the middle of $19^{\text {th }}$ century. Liberals believe that the traditional conservatism was gone astray by the society due to nonexistence of social contract and social change, as they sought only absolutism in government and economic growth.

\section{Liberal Notion}

In the 1632, John Locke developed the theory of classical liberalism focusing on civil liberties under the rule of law, economic freedom, and the social contract. Later, it has been widely developed in the $19^{\text {th }}$ century paying major attention to freedom of speech, freedom of the press, freedom of religion, free markets, civil rights, democratic societies, secular governments, gender equality, and international cooperation (Lessnoff, 1986). Since then, it is more inclined with liberal thought in the context of grassroots organizations operations. Neo-liberals consider that civil societies are capable institutions with the potential to harness social and economic opportunities and deliver efficient basic services. Some author (Blaikie, 2006) believes that grassroots organizations are more proactive and have the trust with the community that attracts a variety of stakeholders to contribute to the service delivery mechanism. Narayan, Patel et al (2000), argue that poor people intend to organize in various organizations, through these they can negotiate with governments, markets, and non-government agencies, and receive the direct assistance to shape 


\section{6| Keshav K. Acharya}

their own destinies. These voices of the poor demonstrate that the local communities and people have a deep sense of involvement/ connection with community-based organizations. These people thought that it was only through grassroots organizations that they could move from scarcity to sufficiency.

However, some scholars (Allen, Smit, \& Wallach, 2005; Wallach, Allen, \& Smit, 2008) believe that liberal notion enforces privatization more than deregulation and collective approach, which results thriving hierarchic power structure on the one hand. On the other hand, the grassroots organizations gradually become incompetent to build trust, reciprocity, and network due to existing hierarchic power structure. Concurrently, the attitude of powerbrokers at the central level insists to decline community groups' belongings at the grassroots level. The number of theoretical and empirical explanations also prove that such compartmentalized policies, actions and process have not only enforced the grassroots organizations to become upwardly accountable, but has also limited their collective or social interests and capture the exercise of democracy and governance.

In the developing countries, the state mechanism has enforced to enact the policy of decentralization in the late 1960s under the framework of neo-liberalism. However, the poor commitment and indolent bureaucracy, less realization of the local communities, sluggish growth of private sectors, and extensive growth of donor agencies led only the de-concentration model. This system created another ladder of bureaucracy that imposed the grassroots organizations to contribute and participate in local project implementation, while their participation in the decisionmaking process was only informal. In addition, this process run community and their institutions were on the periphery, whilst the rural elites, political leaders and service agencies occupied the central controlling position. To empower the citizens, and upsurge their access to power, services and resources especially marginal section of the communities and their institutions, community governance as transformative approach is an apparent. It provides an overall framework for service delivery in an inclusive and equitable manner. 


\section{Transformative Notion}

The transformative notion has largely dismissed the previous arguments which were based on radical and liberal notions, because these were inadequate in describing the grassroots organizations' structure, actions, relationships and their capacities. Transformative notion focuses on the process of perspective transformation under three dimensions: psychological (changes in understanding of the individual), convictional (revision of belief systems, and focuses on social justice), and behavioral (changes in lifestyle) configuration (Khabanyane, Maimane \& Ramabenyane, 2014). Such dimensions are the upshot of the society, which are transformed by the social movements, campaigns, and other popular initiatives. At the end, the combination of these upshots and countless ingenuities contribute to a large scale of transformation of people and their organizations for the richer base of ideas and activities.

In the community perspective, the transformative notion was developed under the structure of governance to contribute the fundamental change in attitude and behavior of both previous arguments and necessitated a new alternative of 'learning by doing' (Stetsenko, 2008). This idea appreciates the grassroots organizations as best vehicle to deliver basic community services. More importantly, this approach transforms the attitude of government, NGOs and donors to formulate more grassroots organizations without any considerations, and discontinuation of the support once the purposes have been served (Martínez, 2008). In this sense, the transformative thought recommends the promotion of sustainability for communities and grassroots organizations.

Banks, Hulme \& Edwards (2015) add that strong grassroots organizations are the dynamic agents for which local people create an environment to reinforce their capacity over time through the support of external actors or a network of organisations. Experiences reveal that grassroots organizations' capacity at local-level planning brings changes in the socio-economic status of the poor, institutional empowerment, gives people a deeper insight into their community and gradually changes the structure of rural power (Talukder, 2004). Examples, such as the the Chipko movement ${ }^{1}$ (Agarwal, 1992) and Jan Swasthya Abhiyan ${ }^{2}$ in India (Campbell, Cornish, Gibbs, \& Scott, 2010), the community forestry movement, rural cooperative ${ }^{3}$ and mother groups ${ }^{4}$ ' movement in Nepal (Chhetri et al., 2007), the rural 
credit movement and Swonirvar ${ }^{5}$ movement in Bangladesh (Huque, 1985), and the Sarvodaya 6 movement in Srilanka (Candland, 2000) are transformative movement that lead to structural shift in the basic premises and an amalgamation of consciousness, negotiation, and mediation, which does not seek merely resolution of the issues, challenges, and inability in grassroots organizations' actions in shortterm, but rather, seeks the empowerment and mutual recognition of the communities.

In the community development point of view, community based governance system is a transformative approach that creates an enabling environment of interaction among government, market, community and various other actors in a balanced manner. Community based governance implies, co-steering, co-regulation, and co-guidance to substitute the traditional top-down, centralsteering, and unfair competition system, while it ensures that no single player has the required knowledge and resource capacity to manage the community issues in a coherent basis.

\section{Evolution of Grassroots Organizations in Nepal}

In Nepal, the ethnically-based groups such as Guthis of the Newars, the Rodhis of the Gurungs, and the Bhejas of the Magars amongst others are the earliest forms of grassroots organizations (Bhattachan, 2002). Apart from these, Bhajans and Kirtan groups are also innovator at the communities level for educating communities about their rights and duties by singing religious songs and dancing (Shrestha, 2004). Although there is limited documented history of these informal organizations, they have been running for generations (Chhetri et, al, 2007). Some of these institutions have been officially legalized in due course of time. Formalized grassroots organizations activity in Nepal was instituted early in the 1950s through Tribhuvan Gram Vikas Project which aimed to improve rural livelihoods (Shrestha, 2004). Later, Societies Registration Act 1959 was promulgated as major legislative instrument to institutionalize the community-based organizations. By the early 1970s, the numbers of grassroots organizations were grown with support of international development agencies. The Small Farmers Development Program (SFDP), Productive Loan Development Program (PLDP) and the concept of integrated rural development program (IRDP) was implemented. The Tuki system, field assistants system, integrated 
village development activities, local-private enterprises, irrigation system approach, Gaun Sallah (village dialogue), mechanism of group organizers, and a problems implementation approach were major initiatives during IRDP stage (Amatya, 1989).

In the 1980s, a slogan of "Self-reliance for Rural Development" emerged with the purpose of giving priority to rural communities' independence in designing and managing their livelihood system. Later, a new generation of community-based savings and credit groups were emerged by the support of local and international NGOs. In the early 1990s, the concept of social mobilization was appeared to bring the actors more closely to determine their needs and demands locally. This concept has long been associated with the movement from traditional to modern ways of life.

In 1990, a major political transformation was held in the country and the 30-years-old party less Panchayat system was collapsed and a new form of democracy was established. The democratic government had created enough space to wider development of grassroots organizations. The Local SelfGovernance Act (LSGA) 1999 and its by-law was formulated as milestone of local development. Based on these Act and by-law, the central government has been decentralized its authority such as planning/project development activities and resource mobilization to lower tire (DDC at district level, municipality and VDC at village levels). LSGA 1999 have given more power to local government and local communities to decide themselves in diagnosing problems, determining priorities, implementation and evaluation of programs coordination with local level non-governmental institutions like grassroots organizations. Similarly, the importance of grassroots organizations in the development process in Nepal was reemphasized after promulgation of Social Welfare Act 1992 with the mandate to facilitate, promote, mobilize and coordinate the activities of grassroots organizations.

In recent years, grassroots organizations' obvious capacity has been seen in the participatory approach in the cooperative movement. Along with this evolutionary emergence of grassroots organizations are formally and informally engaged across the country different sectors including savings and credit, agriculture, non-formal education, irrigation, natural resource management, 


\section{0| Keshav K. Acharya}

multi-functional groups, infrastructure, health, drinking water supply and sanitation. However, the Nepali society is characterized by an ethnically diversified feudal system, complex power structure, elite oriented, pervasive social inequality based on caste, ethnicity, and gender is deeply rooted in culture these phenomena have enforced the local institutions to be limited in certain periphery.

\section{Study Setting}

\section{Research Methods}

The Tawa Khola watershed of Nepal was chosen for the study area because it exhibits the necessary levels of rural endemic poverty and long-term marginalization or exclusion from the basic service structures or mechanisms. In terms of the political divisions, the area belongs to the Udayapur district Eastern Nepal. In 1979, the Sagarmatha Integrated Rural Development Programme covered the study area to reinforce the partnership between the central government and grassroots communities and deliver the basic services at the grassroots (Pradhan, 1985). Nonetheless, this joint effort neglected the traditional community governance system and permitted the rural elites in the power structure to pay even less attention to legitimization and participation of local communities, captured all possible alternatives, created a monopoly in the service system, and destroyed public motivation in institutional development. After reinstate of the democracy in 1990, the District Soil Conservation Office carried out the watershed management programme in Tawa Khola area, both District Development Committee and Village Development Committee jointly commenced the Village Development Programme, and Department of Road commenced the road extension development (Katari-Solu Highway) from this area. Furthermore, number of the government and nongovernment organizations were engaged to carry on the development works under partnership approach with community groups. Based on these development efforts in Tawa Khola Watershed, this study analyses the institutional capability of grassroots level organizations in relation to their service delivery. However, the selected study area found poverty-stricken pockets of Nepal, farthest from the district headquarters and major urban centers. The District Poverty profile reveals that poor households (HHs) in the study area constituted $31.42 \%$ of the population (DDC, 2016). Similarly, HHs having 
access to safe drinking water and sanitation facilities constituted $33.52 \%$ and $43.60 \%$ respectively (WaterAid, 2012).

\section{Data Collection}

In the selection of respondents, the sampling method of Arkin and Colton (1963) was administered. Ninety-five percent confidence level and five percent precision level determined the total population comprising the study area. The proportion of population comprising the sample size was determined by using the following formula (Yamane, 1967).

$$
\begin{gathered}
\mathrm{n}=\frac{\mathrm{N}}{1+\mathrm{N}(\mathrm{e}) 2} \\
\text { Hence, } \frac{\mathrm{n}=152}{1+152(0.05)^{2}}
\end{gathered}
$$

the sample size $=110$

Similarly, the number constituting the sample size was determined by following formula:

Sample Fraction $=\frac{\text { Sample Size }}{X}$ Individual Pop ${ }^{\mathrm{n}}$. of Organizations

Total Population of Respondents

Table 1: Sample fraction of the unit of analysis

\begin{tabular}{lll}
$\begin{array}{l}\text { Description/Type of Organi- } \\
\text { zations }\end{array}$ & $\begin{array}{l}\text { Total Number } \\
\text { of Groups }\end{array}$ & Sample Number \\
\hline $\begin{array}{l}\text { Community Forest } \\
\text { Groups (CFUGs) }\end{array}$ & 44 & 31 \\
$\begin{array}{l}\text { Community Organization } \\
\text { Groups (COGs) }\end{array}$ & 72 & 53 \\
$\begin{array}{l}\text { Women's Development } \\
\text { Groups (WDGs) }\end{array}$ & 36 & 26 \\
\hline Total & 152 & 110 \\
\hline
\end{tabular}

The Community Forestry User Groups were directly involved in natural resource management activities as per government regulations while the Community Development Organization Groups conducted social, economic and infrastructural 


\section{2| Keshav K. Acharya}

development activities at the grassroots level, supported by local government and other development partners. Women Development Groups ensured women's participation and gender inclusion in local development activities at the grassroots level. Overall, the aim of these groups was to promote community governance to facilitate the peace-building process.

A mixed method approach was adopted that triangulated both quantitative and qualitative techniques for data collection, analysis and presentation. Following 6 different parameters with 30 indicators were designed by employing a participatory consensus in group meetings. Experience indicates that such parameters are functional activities of the grassroots organizations, which were developed under the criterion of governance at the grassroots level.

Both quantitative and qualitative data were collected from February to April, 2015. Whereas 110 organizational surveys and three focus group discussions (FGDs) were administered for the primary data collection. In addition, institutional records, such as government policies, government Acts, operational plans and minutes of group meetings, were also collected for the secondary data.

For the FGDs, three scheduled discussions were employed. The participants were chairpersons and secretaries of the grassroots organizations groups in which the institution building, mobilizing communities for community driven development, enabling environment, inclusive participation, practice of local democracy, empowerment of the people, social capital development, service integrity, and coordination, linkage, and partnership were discerned. Each FGD lasted approximately 90 minutes. Proceedings were recorded electronically and later transcribed. An organizational survey was conducted by employing a simple random sampling method in which data were collected during the period of scheduled group meetings. A close-ended structure with multiple choice questionnaires was employed for data collection 45 indicators with 'Yes' and 'No', where 'Yes' denoted the activities completed and 'No' otherwise. Responses were weighted by assigning 1 for completed activities and 0 for otherwise. 
Dhaulagiri Journal of Sociology and Anthropology Vol.11, $2017 \mid 73$

\begin{tabular}{|c|c|}
\hline Variables & Specification \\
\hline $\begin{array}{l}\text { Mobilizing } \\
\text { communities for } \\
\text { community driven } \\
\text { development }\end{array}$ & $\begin{array}{l}\text { - } \text { Institutionalize participatory bottom-up } \\
\text { - } \text { process in grassroots organizations } \\
\text { - } \text { Economic resource mobilization activities } \\
\text { - Transparency and accountability in the actions } \\
\text { - Minimizing the role of political and feudal } \\
\text { elites in the community power structure }\end{array}$ \\
\hline $\begin{array}{l}\text { Enabling environ- } \\
\text { ment }\end{array}$ & $\begin{array}{l}\text { Prepared community based creeds, norms and } \\
\text { - } \quad \text { Palues } \\
\text { - } \quad \text { Lorkide for graining and new skills and scopes of } \\
\text { - } \quad \text { Regitimized (registration process completed) } \\
\text { - } \quad \text { Conducive environment for members }\end{array}$ \\
\hline $\begin{array}{l}\text { Inclusive partici- } \\
\text { pation }\end{array}$ & $\begin{array}{ll}\text { - } & \text { Equal benefit sharing } \\
\text { - } & \text { Leadership selection } \\
\text { - } & \text { Resource mobilization and management } \\
\text { - } & \text { Accision making } \\
\end{array}$ \\
\hline $\begin{array}{l}\text { Practice of local } \\
\text { democracy }\end{array}$ & $\begin{array}{ll}\text { - } & \text { Access to all members in organization system } \\
\text { - } & \text { Leadership selection by people's choice } \\
\text { - } & \text { Access to all members in service mechanism } \\
\text { - } & \text { Freedom to voice raising mechanism }\end{array}$ \\
\hline $\begin{array}{l}\text { Empowerment of } \\
\text { the people }\end{array}$ & $\begin{array}{l}\text { - Access of communities into education, health, } \\
\text { - Access to management positions } \\
\text { access of communities into income generating } \\
\text { of production organizational change } \\
\text { - Community Transformation }\end{array}$ \\
\hline $\begin{array}{l}\text { Social capital } \\
\text { development }\end{array}$ & $\begin{array}{l}\text { - Increasing cooperation, relationships and } \\
\text { cohesiveness at the community } \\
\text { Increasing trust of local people in grassroots } \\
\text { organizations activities } \\
\text { - Increasing social and economic interaction } \\
\text { among the grassroots organizations } \\
\text { - Social actions of grassroots organizations } \\
\text { enabled to change the public perception from } \\
\text { individual to collective action } \\
\text { Enactment of social norms, values in service } \\
\text { mechanism }\end{array}$ \\
\hline
\end{tabular}

Source: Author, February-April, 2015 


\section{4| Keshav K. Acharya}

\section{Data Analysis}

For the data analysis, both quantitative and qualitative techniques were applied. Initially, a composite index technique (CIT) was employed to analyze the quantitative data. The CIT is a scaling method that measures responses with respect to quantitative attributes or traits. For example, a scaling technique might involve estimating an individual level of extraversion, or the perceived quality of products. A grouping of indices or other factors combined in a standardized way provides a useful statistical measure of overall market or sector performance over time (Foa \& Tanner, 2011). The following CIT was administered to analyze the quantitative data:

$\mathrm{C}_{\mathrm{j}}=\sum \sum \mathrm{Wi}, \mathrm{nI}$

$\mathrm{C}_{\mathrm{j}}=$ Composite Index Technique of activities, weight given to individual institutions as per the performing activities,

$\mathrm{Wi}=1$ and $0(1=$ activities performed, $0=$ Not Performed $)$, $\mathrm{n}=$ Number of organizations under the particular categories and,

$\mathrm{I}=$ Number of indicators taken under each category of broad functional groups.

This method assists to measure and compare the organizations' contribution and performance in the different service activities. Based on composite index values, the grassroots organizations' contribution was categorized into four classes, as follows: efficient $=$ above 0.75 , moderate $=0.50-0.75$, weak $=$ $0.25-0.50$ and very weak $=$ less than 0.25 . Later, the quantitative result was triangulated by employing qualitative data analysis.

\section{Results and Discussions}

Grassroots organizations capacity is a comprehensive outcome of the many attributes that are accomplished by an interaction of organizational physical entities and social capital of organizations. Following table presents the grassroots organizations effectiveness in service delivery mechanism at the grassroots level. 


\begin{tabular}{|c|c|c|c|c|c|c|c|}
\hline 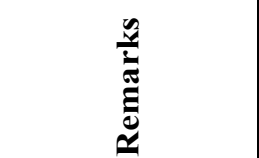 & 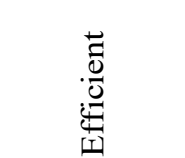 & 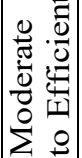 & 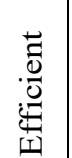 & 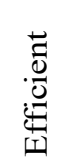 & 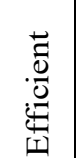 & 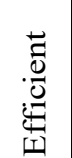 & 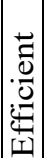 \\
\hline " & $\begin{array}{l}\infty \\
\infty \\
0\end{array}$ & $\begin{array}{l}0 \\
0 \\
0\end{array}$ & $\begin{array}{l}\vec{\infty} \\
\dot{0}\end{array}$ & $\frac{0}{0}$ & $\stackrel{N}{0}$ & $\hat{0}$ & $\hat{0}$ \\
\hline 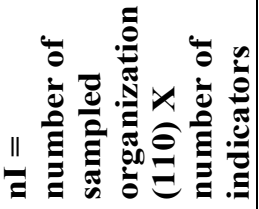 & $\begin{array}{l}\stackrel{n}{n} \\
i n\end{array}$ & $\begin{array}{l}\circ \\
n \\
n\end{array}$ & $\begin{array}{l}\stackrel{0}{n} \\
n\end{array}$ & $\begin{array}{l}\stackrel{0}{n} \\
n\end{array}$ & $\begin{array}{l}\stackrel{n}{n} \\
n\end{array}$ & $\begin{array}{l}\circ \\
n \\
n\end{array}$ & \\
\hline W: & $\stackrel{n}{\infty}$ & $\begin{array}{l}n \\
m \\
m\end{array}$ & $\stackrel{n}{\stackrel{f}{*}}$ & 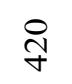 & ๙n & $\stackrel{\sim}{\sim}$ & \\
\hline WW & $\hat{a}$ & $\stackrel{m}{r}$ & ஓे & $\infty$ & 9 & 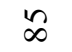 & \\
\hline 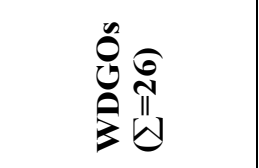 & $\infty$ & $\infty$ & $\vec{\sim}$ & $\vec{\sim}$ & 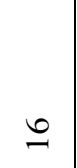 & $\infty$ & \\
\hline ڤ̆ & $\stackrel{i}{n}$ & $m$ & †े & ஓ & $\stackrel{\sim}{f}$ & ஓ & \\
\hline$\underset{b}{\infty}$ & حे & 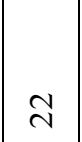 & 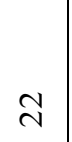 & 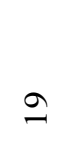 & $\vec{N}$ & $\stackrel{\sim}{\sim}$ & \\
\hline 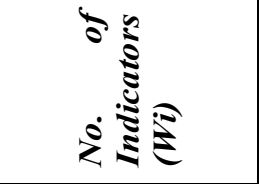 & $n$ & $n$ & $n$ & $n$ & $n$ & $n$ & \\
\hline 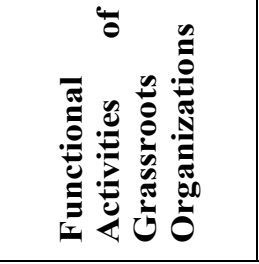 & 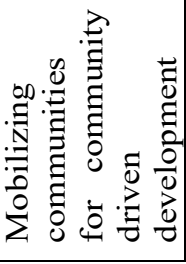 & 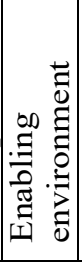 & 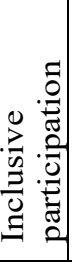 & 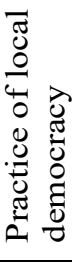 & 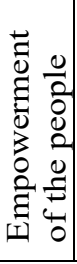 & 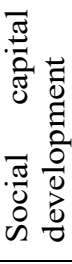 & 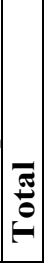 \\
\hline
\end{tabular}




\section{6| Keshav K. Acharya}

The capacity of grassroots organizations and their performance in the study area was analyzed through seven functional activities, which found Efficient $(\mathrm{CI}=0.77)$. Table 3 and above figure illustrate that the functional capacity of the grassroots organizations groups in the community service delivery mechanism was fairly efficient in 5 different activities such as, mobilizing communities for community driven development $(\mathrm{CI}=0.88)$, inclusive participation $(\mathrm{CI}=0.81)$, social capital development $(\mathrm{CI}=0.77)$, practice of local democracy $(\mathrm{CI}=0.76)$, and empowerment of the people $(\mathrm{CI}=0.72)$, while enabling environment $(\mathrm{CI}=0.66)$ remained with Moderate to Efficient category.

Following to result of grassroots organizations' capacity and their performance for service delivery measure in study area was Efficient due to various measures. First, grassroots organizations played an important role in addressing inequality, isolation and poverty through educating informing and communicating to all segments of the communities about the services mainly income generating, saving credit, health and education, social welfare, community planning and local resource management. Second, they fostered awareness creation, democratic exercise, governance practice, coordination and linkage and network development via building partnerships to both public and private sectors. Such linkages may improve the efficiency of the entire sector and create new opportunities for employment. Third, grassroots organizations facilitated to mobilize local resources and adopt accountability measures such as public auditing and project book. Finally, the voices of the rural communities brought to the local government council and then through authentic government channels to be included in the national development plans. It is a new initiative of community mobilization in Nepal, stressing the need to engage with local government to secure services and resources for better livelihood, better access to health services, and safe drinking water and education facilities for communities. A Women Development Group member of the watershed area expressed that;

We are 22 members in the women group, after being organized in the group, we brought a big change not only in our socioeconomic pattern, but also change can be established in community development pattern, as she said earlier the women in the village were not aware about the village and district level block grants and where the development budget was spent. Now we know that 
there is $35 \%$ government budget allocated for the development of women, children and the disadvantaged groups.

Despite these, grassroots organizations were reluctance to address the issues, due to inept that might not be considered as prioritized actions, as result grassroots organizations' capacity and their performance remained merely moderate to efficient. Although the formation process of grassroots organizations was either led by sponsored activities (local government, line agencies, donors, NGOs) or run by enforcement activities, the public self-motivation, engagement, voice raising mechanism, grievance sharing and social capital development was higher. The primary reasons behind this was the sponsored grassroots organizations were highly powerstructured; more concerned with resources, upwardly accountable to the funding agencies, lacked inclusivity in their leadership, and turned away from volunteerism and social movements against injustice.

Empirical information shows the formation of grassroots organizations groups in the study area began during the 1960 s to intervene in the vicious circle of rural poverty through effective basic service delivery under the Integrated Rural Development Programs (IRDP). Many arguments under IRDP concept illustrate that those grassroots organizations as social agents were highly capable of filling the gap of service delivery and creating awareness of the poor communities. Nevertheless, some information such as lack of proper orientation and the absence of self-reliance concept, and exclusion created a syndrome of dysfunctionalism at the grassroots level. This process declined the peoples' hopes and aspirations, and created confusion to the users, the choosers and the actors in the community service mechanism.

\section{Mobilizing Communities for Community Driven Development}

Institutional capacity indicates that CFUGs were highly resourceful which mobilize the resources in different community-based infrastructure initiatives. These were the constructions of school and community buildings, small bridges and culverts; informal literacy programs, income generating activities for women and the poor; education scholarships for the children of poor and marginal families; paying salaries for local school teachers; and other 


\section{8| Keshav K. Acharya}

emergency actions. In addition, CODGs and WDGOs were also received minimal resources from the local governments, sectoral agencies and I/NGOs for the construction and maintenance of rural roads, irrigation canals, drinking water systems, and many other projects such as training, income generating, and awareness raising programs. These initiatives were indicative of the high level grassroots organizations commitment in community development and resource mobilization. These initiatives were indicative of the high involvement of the community in the activities of the CFUGs. However, some groups were influenced by the abnormal or corrupt behaviour of most group leaders'. They violated the rules, regulations, policies and programs. Most of the CFUGs were dominated by the elites, which provided large benefits to better-off in compared to those who are poor. Following the group facilitation was of particular importance to the group members, as statement of the participant;

The CFUGs in this village are not language friendly; their key executive positions are occupied by 'Hune Khane Haru' (elites).

Additionally, some cases found that projects were implemented by non-beneficiary groups and the real users were excluded from the implementation process. Some participants expressed the view that the chairperson and treasurer captured the resources and used it for their personal benefit. They invested the groups' money in a personal loan and took benefit from the 18 percent interest rate. According to them, the interest income was not deposited in the group account. Similar experiences were found in the CODGs and WDGOs. In these groups, the chairperson and manager either worked as school teachers or were engaged in local businesses. This meant that they were not ready to take on an extra burden such as consolidating the development agencies' resources for community service delivery. Some participants expressed that the grassroots organizations were incompetent; lack knowledge for networking; patronage of government such as Department of Forestry, Women Development Office, and donor agencies such as United Nation's supported development projects; and beyond from the apolitical nature. These led to sluggish to manage the various socio- community infrastructure works, carry out to public auditing compliance requirements, encourage people for public contribution and collective actions, and transparent in community financial 
management systems. In addition to these shortcomings, they were guilty of underestimating the costs of projects, lacking the technical skills to implement the projects, shirking their responsibility to be accountable, and practicing poor management processes.

Despite many limitations mentioned above, many experiences indicate that after the implementation of decentralization in the late 1980s under the framework of neo-liberalism and social mobilization-based schemes such as the Village Development Program, the Community Forestry Program, and the Women Development Program in the study area, many intensive interactions, exposures, and training packages were offered by the development agencies to enhance the capacity of the grassroots organizations and the local people. These bolstered the capacity of local institutions and people to thwart societal malpractices such as corruption, complex bureaucracies, exclusion, irresponsive governance, and non-participatory democratic practices. Thus, some grassroots organizations as self-organizing institutions proved their capacity in identifying needs and taking decisions for effective solutions, formulating simple rules and strong incentives, providing technical and material support to community development, enhancing community capacity through existing indigenous skills and knowledge, fostering economic capacity development through enterprise development and capital formation, and in many other social transformation capabilities.

\section{Creating Enabling Environment}

'Enabling environment' is an expression which encompasses policies, rules, regulations, strategies, and legal processes that focus on effective service delivery. Recently, technology and market have been appreciating overwhelmingly as major enabling factors of service delivery. Grassroots organizations created appropriate environment not only to empower the local people and prepare them to be a part of resource management process but also the agents to pay greater attention to ease of access to quality education and a sound health system, together with the necessary infrastructure and financial service mechanisms at the community level. The information shows that all the CFUGs' at the grassroots level in the study area were legitimized by Forest Act of Nepal, 1993 and other institutions were legitimized by the Cooperative Acts and local 


\section{0| Keshav K. Acharya}

government mechanism of the country.

In spite of the number of best practices for capacity development of local people, grassroots organizations lost their public image and identity and they were diverted from social empowerment and community governance to only economic benefit. The local people claimed that many grassroots organizations formulated internal rules, regulations and creeds, but these were not adopted and exercised by grassroots organizations effectively. The poor implementation mechanism, lack of technical support, supplyled approaches, and elite influence remained the role of grassroots organizations was controversial. The following participant's opinion supports this finding:

Not only government policies, rules, and regulation, but also the internal mechanisms of grassroots organizations, and their service systems are not all effective. The selection of leadership and other decision making processes such as formulation of plans and projects, mobilization of resources and decision making processes are power structured, which does not encourage people's participation and their access to the service system.

Following the statement above, some participants claimed that the rules, regulations, creeds and guidelines, which CBOs formulated, adopted and exercised were not effective, due to poor implementation and lack of technical support. Such policies resulted into several confrontations among the community actors such as deliberative alliance between local government and community, mobilizing community resources (saving and credit policy), utilizing natural resources (orientation of forest, sustainable use of forest resources), village gathering, community physical contribution, and downward accountability. Regardless, some groups also felt that a reward and punishment system enhanced the CBOs' enabling environment for effective service delivery. This is a motivating factor for the effective function of communities and institutions. Some initiatives were introduced such as assessing the performance of groups and members, conducting community initiated social and economic actions, providing community owned contributions, and resource utilization. Experience shows such practices were popularized and institutionalized in the community service mechanism. 


\section{Inclusive People's Participation}

People's participation is appreciated as a valuable component of service delivery which bolsters downward accountability, public rights and their satisfaction while eliminating unnecessary bureaucratic complexities, risks of corruptions and elite capture. Empirical findings point out that some grassroots organizations were incapable to design the configuration of group formulation, their structure, leadership, linkeges and facilitation, and creeds and guidelines that could not encourage the people for their meaningful participation. The major reasons were that group meetings were either not conducted in regular basis or meetings were organized without prior notice. Some groups conducted group meetings only for formality and concluded the meeting with no agendas and issues. There were no ground rules or regulations; many members were not aware of their role and responsibilities, so that they usually participated in the meetings as silent listeners; and most of the important decisions were not recorded. These kinds of activities created three types of issues in decision making. The first was low attendance of members mainly from the segments of the weaker and vulnerable class and created an environment of domination by the rural elites. Secondly, there was no guarantee that they would listen to the voices of the impoverished communities. The third issue was manipulation of records. These issues led to the grassroots organizations being incompetent in the service mechanism.

Despite these realities, many grassroots organizations have brought numerous positive changes in the decision making system and have increased the community influence in power structure. For example, saving credit activities, formation of resource mobilization groups, village gathering, community physical contribution, and information sharing were most notable activities. A participant's comment shows how grassroots organizations' activities have resulted into inclusive participation:

As CFUGs, we are the best alternative and resourceful institutions for community development. We are not only engaged in forest resource management and its utilization, but also actively contribute to managing community capital formation and resource mobilization process. We have made contributions to community infrastructure development and even a few scholarships for the children of poor and marginal groups. These are the inclusive actions of people's participation. 
Following the statement, resource management and utilization are the key strength of inclusive participation that widens the institutional space, encourages innovative citizen-oriented management techniques, and civic infrastructure. Many examples exist to show that grassroots organizations have been transformed from individual to collective thinking entities. In this process, they developed collective leadership, abandoned social partiality, discrimination, and exclusionism, which ensured easy access to the organizational structure through a participatory planning process. Many participants explained that the development from individual to collective action signified the end of the centralized system, which initiated new opportunities for marginalized sections of the population.

\section{Practice of Local Democracy}

Local democracy is a process whereby community actors' become accountable to the communities and responsible for the community needs and aspirations. Empirical finding also confirms that two types of democratic systems were being practiced in the study area. These were participatory democracy and democratic centralism. The first involves a consensus system that offers greater political representation, whereas the latter is concerned with the majority vote. Examples further show that many grassroots organizations were involved in strengthening leadership in the school management and water and sanitation committees as a result, grassroots organizations are becoming advocacy mechanism in decision making and resource management at local area in general. Nevertheless, some issues contributed to the weak democratic practice at the community level. The following observation shows the community people to be suppressed by the abuse of the majority-based democracy, which created an inter-community conflict between original dwellers and migrants.

As original dwellers we built CFUG, formulated guidelines, demarcated fire lines, replanted and rehabilitated the barren land. However, we have become a minority now. After the migration from hill districts during the period of conflict, migrant numbers are higher than us. Now, they hold the key position in committees due to the majority based democratic system. Being in the majority, they have formulated policies, rules and regulations according to their advantage which has violated the CFUGs norms and rules. 
However, the democratic practice has supported them for their actions.

The statement clearly indicates the structural conflict, which was arisen due to majority based democratic practices. First, the political and social transition of the communities forced the grassroots organizations to bypass the steps of democratic practices such as selection of representatives, empowering leadership capacity, benefit sharing, a culture of acknowledging others' opinion, and practicing a participatory decision-making process. Second, they were unsuccessful to encourage the people to involve in voice raising mechanism, and grievance sharing apparatus. These process deteriorated partnership with demandresponsive support organizations and service providers including local governments, the private sector, NGOs, and other sectoral government agencies. Consequently, a fertile ground was amplified for upward accountability, and encouraged the community actors and leaderships to abuse their position of power. Such negative experiences discouraged the participation of women, Dalit and marginal communities in service reception. Some participants expressed the view that they did not have interest in this type of power mechanism. Many participants complained to the selection process of organization leadership that was lack participatory, and members were under pressure to follow the development agencies' instruction. Thirdly, manipulation of information obstructed the people from sharing their knowledge, views, and ideas in the grassroots organizations.

Irrespective that many experience of grassroots organizations shows that a strong local democratizing practices was instituted that enforced local leaderships to be accountable with people's and their institutions. The study findings reveal that local democracy at the community level produced two outcomes. First, it contributed to replacing the hierarchical power structure with community organization. Secondly, this new structure placed the community at the center and helped increase governmental effectiveness for accessible, equitable and quality-assured service delivery.

\section{Community Empowerment}

Community empowerment is concerned with the process of acting 


\section{4| Keshav K. Acharya}

collectively, such that it enhances community impact on, or provides control over decisions that influence their interests. In a multidimensional process, empowerment is embedded together with local value and belief systems, which helps people or groups to gain power and control over their own lives. In this respect, many groups' engagement was to bring a social and economic changes at the community level. They developed leadership capacity of the group members, mainly women and marginal communities; increased effectiveness of group meetings, identified refined agendas, and made concrete decisions. They also oriented the people about the social and economic issues that supported the enhancement of knowledge and skills for effective of planning, implementation and monitoring; and also reduced untouchability as well as discriminations based on gender and social strata. Similarly, they were playing the role of social pressure groups to institutionalize community governance, promoted collective efforts in local resource mobilization, and developed horizontal and vertical relationships. Following three conditions such as transparent democratic practices in community actions; appropriate facilitation of members; and positive action by the rural elites, who were normally in leadership positions, contributed to making a real difference towards inclusive participation played key role for peoples' empowerment.

Despite the mentioned facts above, there are other opinions as well that the degree of achievement varied according to grassroots organizations groups. The participants' comments reveal that the orientation of development agencies and their service delivery pattern, implementation modality, process and system and group dynamics did not create much interest and so that they were not able to stimulate the people for self-mobilization and self-regulation. A participant expression is particularly relevant in addressing this issue:

We need an improved irrigation and drinking water system; skilled health workers for midwifery services; trained extension workers of livestock and agriculture service for income generating activities; we need government schools as we are unable to send our children to highly expensive boarding schools; we need market facilities to sell and buy our local products; and a road link with the market centre. However, grassroots organizations neither can fulfil our expectation nor can build productive relationships with funding agencies. 
In this matter, grassroots organizations in the study area were only partially successful in leading social, economic and institutional challenges. Many cases found that the development agencies were worked in a structured mechanism. Although such mechanism fulfilled the little gap of service delivery and resources availability, and brought some tangible results at the community level, the consequences of the implemented activities were either weak in terms of sustainability or there was lack public ownership. Some experiences indicate that most of the groups' resources were invested in economically unproductive sectors such as temple construction, trail maintenance, motorcycle/cycle repairing training, and sewing training, because such projects were designed under the interest of certain leaders. To launch these projects, leaders were already convinced to the funding agencies that such demands were from the people's assembly. The funding agencies were also happy to support anything that was the 'people' tag and ready to provide huge amount of resources without any monitoring mechanisms. In reality their support could not contribute in overcoming community suppression. This type of flawed intervention favoured upward accountability and a supply-driven system, increased outsiders' influence, minimized the role of local people, and increased the misuse of resources.

Notwithstanding such shortcomings, there were a number of specific factors that contributed grassroots organizations' empowerment. First, the deliberative alliance between local government and community with institutional facilitation contributed to empowering communities. Under this alliance, the local community received a regular annual budget from the local governments for social empowerment schemes. Second, the strategic alliance among the government organizations, NGOs and communities enhanced local capacity. Evidence shows that the NGOs and donors were also supported with software packages to foster social mobilization, raising voices, claiming assets and services, and having an influence in the decisions, procedures and the formal and informal rules of the game. Third, communities under the groups' leadership appreciated their role in community initiatives; they exerted pressure on the development agencies for downward accountability and were involved as a major stakeholder in the development process. 


\section{Building Social Capital}

Community practices at the grassroots level created new social forums for public gatherings to identify their need-based demands, review their past experiences, and facilitate the social support system. They also contributed to increasing social cooperation, relationships and cohesiveness among the group members. Apart from these, community people were involved in different types of democratic exercise that have enhanced the peoples' managerial and leadership capacity, improved bargaining and dealing competencies that gradually replaced the community power structures and monopoly of elites. These led to improve inclusiveness of the poor and marginal groups in the group dynamics, increase reciprocity and more public trust in grassroots organizations and formation of new networks with different stakeholders. Experiences show that networks supported in strengthening old links and broke down the social and bureaucratic formalities and has created enabling rules. This type of grassroots organizations' role contributed to socioeconomic improvement and effective service delivery mechanism at the grassroots level.

In addition to these, there were a number of examples that reinforced high capacity of the grassroots organizations mainly the CFUGs. First, the community received high value forest resources. After devolution, the control of local forest by the communities and their access to the forest greatly enlarged. Despite these, some disapprovals came to view that CFUGs were adopted technobureaucratic and corporate culture that replaced indigenous ways of community governance and by placing market elements into existing hierarchies and power asymmetries of local communities. Secondly, the provision to invest a certain amount of the income in community development and livelihood assets was established. This practice encouraged commercialization not only to increase demands and surplus supply but also combined the economic and non-economic factors for next possible step in communitymanaged resources. Thirdly, many best practices demonstrated that grassroots organizations not only manage the local resources for their immediate benefits, but also engage as a social agency for community transformation, social inclusion, establishment of a democratic culture and governance system. These experiences of grassroots organizations proved that the capacity-building training, 
exposure tours, regular group meetings, grievance sharing, and social mobilization activities had a multiplier effect in the social capital-building process.

However, some grassroots organizations groups were deficient in social capital development activities. The lack of careful dealing in the service mechanism, lack of information flow for benefit sharing, non-users' participation in the project user committees, lack of transparency in the activities and resources led to public dissatisfaction in the grassroots organizations' activities, which directly affected the social capital building process. Similarly, CBOs actions without assessment of community based norms, values, and service quality posed to the poor and marginal groups' exclusion, lost public trust in the service mechanism Despite such limitations, grassroots organizations proved highly efficient in mobilizing communities with inadequate resources. Following to address the context, one participant expression was more realistic that:

We are so-called Dalit, our life is in the high risk of extreme poverty, so that, we are unable to participate in each group meetings. We have not only time factor to participate in each group meetings, but also do not feel comfortable in the meetings, because, they discuss yonder our requirements. We need food stuffs for every day, clothing to our children, shelter to our families, while their priorities are on the irrigation project, bitumen for the road, and bridge construction. Last year, we put the demand to provide the job for paid physical labour in road construction project, whereas they constructed the road with expensive excavators. In this situation, we do not have trust the group to readdress our grievances.

The power structure in community services shows the feudal social hierarchy's influence in the social, economic and political spheres of community that hampered to the public participation, destabilization of socio-politics and economic structures, creating uncertainty and the pressures on local people and their organizations structure. Despite the proclamation, there was two distinct logics that created social capital at the community level in general. These were: proximity, people from the same locality will tend to be in groups; and common interests as well as common professions. These communities based practices created several opportunities such as enlarging the capabilities of self-governance, increasing accountability including leadership selection and the bargaining 
capacity.

\section{Conclusions}

At the community level, grassroots organizations play an important role in addressing problems associated with inequality, isolation and poverty. They foster to create awareness and building confidence, practice democracy and governance, coordination and two way relationships between the community and other stakeholders. They also facilitate to mobilize the local resources, implement a needsbased approach of community development, give 'voices to the voiceless', and build a social-safety net for marginal communities. These processes diminish structural exclusions, reform conflicting policies, increase access of marginal communities to services, strengthen rule of games, and advocate for community wellbeing. Despite many efforts, grassroots organizations have not been able to enhance the status of communities to a satisfactory level. The weak capacity and loose structure, lack of formal legitimacy and resource scarcity in many grassroots organizations caused a failure in managing efficient service delivery and meeting public satisfaction. To this end, the government of Nepal has enforced the policy of decentralization in the late 1960s to strengthen capacity of societal networks. This has strengthened the communities' engagement in governance, reinforced the idea of local self-governance at the local level through the Forestry Sector Master Plan 1989, Cooperative Act 1992, LSGA 1999. These legal instruments created an opportunity for the communities and their institutions to enhance their capacity.

According to empirical evidence grassroots organizations' capacity found from the study in Tawa Khola watershed, the capacity is interlinked with a number of interdependent elements such as organizational structure, knowledge and skills, and resources that have enlarged their capacity on effective community service mechanism. These elements contributed to transforming patron-client relationships from the individual to the community, and upward to downward accountability. Despite these, few cases disclose that they were still facing many crises, both within and external to their organizations, regarding their nature, activities, and functions. The causes were weak capacity of the grassroots organizations and reluctance of group leaders to lead the members, and the assemblies. Many groups violated the rules, regulations, policies and programs in which many projects were implemented by 
non-beneficiary groups and the real users were excluded from the implementation process. To switch of the issues, the government of Nepal put forward the idea of local self-governance at the local level in 1999 that will increase the partnership of grassroots organizations in bottom-up planning, resource mobilization and service delivery.

\section{References}

Acharya, K. K. (2016a). Determinants of community governance for effective basic service delivery in Nepal. Dhaulagiri Journal of Sociology and Anthropology. 10, 143-178.

Acharya, K. K. (2016b). Impaired governance limiting communities' access to service delivery system in Nepal, Himalayan Journal of Sociology and Anthropology, 7: 40-74.

Acharya, K. K. (2015). Community governance and peacebuilding in Nepal. Rural society, 24(1), 65-84.

Agarwal, B. (1992). The gender and environment debate: lessons from India. Feminist studies, 18(1), 119-158.

Agrwal, A., \& Gibson, C. (1999). Enchantment and Disenchantment: The Role of Community in Natural Resource Conservation. World Development 27(4), 629-649.

Allen, C., Smit, I., \& Wallach, W. (2005). Artificial morality: Topdown, bottom-up, and hybrid approaches. Ethics and Information Technology, 7(3), 149-155.

Amatya, S. L. (1989). The Divergent Approaches of IRDPs and Problems of Implementation in Nepal. Contribution to Nepalese Studies, 16(1), 43-54.

Arkin, H., \& Conlton, R. (1963). Table of statistics. New York: Barnes and Noble Publication.

Banks, N., Hulme, D., \& Edwards, M. (2015). NGOs, States, and Donors Revisited: Still Too Close for Comfort?, World Development. 66 :707-718,

Baroi, H. S., \& Rabbani, G. (2011). Community driven development in Bangladesh: Factors behind the reality. Canadian Social Science, 7(4), 74-81.

Batley, R. (2006). Engaged or divorced? Cross service findings on government relations with non-state service providers. Public Administration and Development, 26(3), 241-251. 
Bell, P., \& Cloke, P. (1989). The changing relationship between the private and public sectors: Privatisation and rural Britain. Journal of Rural Studies, 5(1), 1-15.

Bhattachan, K. B. (2002). Traditional local governance in Nepal. Paper presented at the National seminar on strengthening decentralisation and good governance in Nepal, Kathmandu, 21 April. Accessible at: http:// www.nepaldemocracy.org/institutions/traditional_localgovernance.htm

Blaikie, P. (2006). Is small really beautiful? Community-based natural resource management in Malawi and Botswana. World Development, 34(11), 1942-1957.

Boliari, N., \& Topyan, K. (2011). Conceptualizing institutions and organizations: A critical approach. Journal of Business \& Economics Research 5(1), 1-10.

Campbell, C., Cornish, F., Gibbs, A., \& Scott, K. (2010). Heeding the push from below. Journal of health psychology, 15(7), 962.

Candland, C. (2000). Faith as social capital: Religion and community development in Southern Asia. Policy Sciences, 33(3), 355374.

Chhetri, A., Joshi, N. M., \& Maharjan, K. L. (2007). Intervention on Livelihood Management through Community-Based Organizations: Evidence from Rural Nepal. Journal of International Development and Cooperation, 13(1), 187208.

DDC (District Development Committee). (2016). Participatory district periodic plan of Udayapur district (2015-2019). Udayapur: District Development Committee.

deSouza, P. R. (2003). The struggle for local government: Indian democracy's new phase. Publius: The Journal of Federalism, 33(4), 99-118.

Dongier, P., Van Domelen, J., Ostrom, E., Ryan, A., Wakeman, W., Bebbington, A., . . . Polski, M. (2003). Community Driven Development A Sourcebook for Poverty Reduction Strategies (Vol. 1, pp. 303-328). Washington D.C: The World Bank

Foa, R. (2008). Social institutions and human development. Social 
Dhaulagiri Journal of Sociology and Anthropology Vol.11, $2017 \mid 91$

Development Working Papers. Social Development. Washington DC: The World Bank.

Hasan, R., Mitra, D., \& Ulubasoglu, M. (2007). Institutions and policies for growth and poverty reduction: The role of private sector development. Asian Development Review, 24(1), 69-16.

Huque, A. S. (1985). The politics of local government reform in rural Bangladesh. Public Administration and Development, 5(3), 205-217.

Greenberg, G. (2001). The Radical Face of the Ancient Constitution. Cambridge. Cambridge University Press.

Khabanyane, K.E, Maimane, J.R, \& Ramabenyane, M.J. (2014). A Critical Reflection on Transformative Learning as Experienced by Student-Teachers during School-Based Learning. Mediterranean Journal of Social Sciences. 5(27). 452-459.

Kindness, H. \& Gordon, A. (2001). Agricultural Marketing in Developing Countries: The Role of NGOs and CBOs, Chatham, UK, Natural Resources Institute.

Lessnoff, M. H. (1986). Social contract, Macmillan.

Martínez, R. A. B. (2008). Grassroots support organizations and transformative practices. Journal of Community Practice, 16(3), 339-358.

McPhee, P. \& Bare, J. (2001). Introduction. In De Vita, C.J \& Fleming C. (Eds.), Building Capacity In Nonprofit Organizations. Washington, D.C., The Urban Institute.

Narayan, D., Patel, R., Schafft, K., Rademacher, A., \& KochSchulte, S. (2000). Voices of the poor: Can anyone hear us. Washington, D.C.,: Oxford University Press.

Nelson, J. (2007). Building linkages for competitive and responsible entrepreneurship. Harvard University and UNIDO.

North, D.C., (1993). Institutions and Credible Commitment. Journal of Institutional and Theoretical Economics, 149(1), 11-23.

Ostrom, E. (2007). Adiagnostic approach for going beyond panaceas. Proceedings of the National Academy of Sciences, 104(39), 15181-15187.

O’Toole, K., \& Burdess, N. (2004). New community governance in small rural towns: The Australian experience. Journal of Rural Studies, 20(4), 433-443. 
Paudel, G. S. \& Thapa, G. B. (2001). Local Organizational Capability for Land Management: A SWOT Analysis of Organizations in the Hills of Nepal, Asia Pacific Journal of Rural Development, 11(2): 15-34.

Pradhan, B. P. (1985). Integrated rural development projects in Nepal: A review. Ocasional Paper, no. 2 (pp. 1-69). Kathmandu: ICIMOD.

Prasain, J. N. (2008). Development of water supply and sanitation facility in the rural areas of Nepal: An overview. Occasional Papers in Sociology and Anthropology, 8(0), 105-127.

Shaktin, G. (2009). Community-Based Organizations, Local Politics and Shelter Delivery in Metro Manila. Kasarinlan: Philippine Journal of Third World Studies, 14(3).

Shrestha, D. M. (2004). Country papers: Nepal. Paper presented at the role of local communities and institutions in integrated rural development, Asian Productivity Organization Iran, 15-20 June. Accessible at: http://www.apo-tokyo.org/ publications/wp-content/uploads/sites/5/pjrep-icd-se-3-01. pdf.

Soderbaum, P. (1992). Neoclassical and institutional approaches to development and the environment. Ecological Economics, $5(2), 127-144$.

Stetsenko, A. (2008). From relational ontology to transformative activist stance on development and learning: expanding Vygotsky's (CHAT) project. Cultural Studies of Science Education, 3(2), 471-491.

Talukder, A. A. (2004). Country Papers: Bangladesh. Paper presented at the Role of Local Communities and Institutions in Integrated Rural Development, 15-20 June, Iran.

UNDP/N, (2009). Nepal Human Development Report: Making State Transformation and Human Development. Kathmandu. United Nations Development Programme.

Uphoff, N. (1993). Grassroots organizations and NGOs in rural development: Opportunities with diminishing states and expanding markets. World Development, 21(4), 607-622.

Urry, J. (2000). Sociology beyond societies: Mobilities for the twenty-first century: Psychology Press.

Veltmeyer, H. (2005). Democratic Governance and Participatory 
Dhaulagiri Journal of Sociology and Anthropology Vol.11, $2017 \mid 93$

Development: The Role of Development NGOs. Whitehead J. Dipl. \& Int'l Rel., 6, 89.

Wallach, W., Allen, C., \& Smit, I. (2008). Machine morality: bottomup and top-down approaches for modelling human moral faculties. Ai \& Society, 22(4), 565-582.

WaterAid, (2012). Dang: Drinking water and sanitation profile. Kathmandu: Water Aid Nepal and FedaWATSAN.

Yamane, T. (1967). Elementary sampling theory.New Jershy: Prentice-Hall Englewood Cliffs.

\section{(Endnotes)}

1. The Chipko Movement or Chipko Andolan was primarily a forest conservation movement in India that began in 1973 and went on to become a rallying point for many future environmental movements all over the world it created a precedent for starting of non-violent protest in India.

2. The Jan Swasthya Abhiyan is the Indian circle of the People's Health Movement, a worldwide movement to establish health and equitable development as top priorities through comprehensive primary health care and action on the social determinants of health. The Jan Swasthya Abhiyan coalition consists of over 20 networks and 1000 organisations as well as a large number of individuals that endorse the Indian People's Health Charter a consensus document that arose out of the Jan Swasthya Sabha held in December 2000 when concerned networks, organisations and individuals met to discuss the Health for All Challenge.

3. The co-operative concept in Nepal was emerged through the form of Guthi, Parma, Dhikuri, Dharmabhakari. For the institutional development of such societies, the then government aimed to adopt co-operative system as a means for economic social and cultural development of the people as well as an appropriate and effective tool for rural development. The then government established the Department of Co-operative under the Ministry of Planning, Development and Agriculture in 1953. The modern cooperative movement initiated from Rapti Valley as a part of flood relief and resettlement program. In 1959, Co-operative Societies Act 
was formulated and later it was replaced by the Sajha Societies Act in 1984. In 1992, a more democratic Co-operative Act was promulgated which has provided the authority for registration and regulations of co-operative societies/unions/federations. The Cooperative movement emphasized on the concept of self-help in order to accelerate the development process at local level aimed to mobilize resources for socio-economic development of people.

4. Mother's group is perhaps one of the most universalized traditional voluntary organizations in Nepal. It first started with the Gurungs communities of Western Nepal. As most of the Gurung men used to join in the Lahure (British Army, and Indian Army), for the last two centuries, Gurung women formed mother's group to sing, dance, and organize cultural activities in the evening. One of the most interesting activities they perform is to welcome returnee Lahures and guest visitors. They Lahures and guest visitors donate money to the Aama Samuha. Ama Samuha usually organize singing and dancing programs in the evening and collected money is used to build trails, temples, etc. Many INGOs and NGOs have formed and promoted Aama Samuha across the country among different caste and ethnic groups. The Aama Samuha of Bahun-Chhetri castes have very aggressively raised anti-alcohol movement in the villages.

5. Swanirvar Movement a 'basic need' centred approach to rural upliftment and community development which attempted to include various groups within the village structure. The swanirvar (selfreliance) movement constitutes a milestone in the history of rural development in Bangladesh. Pioneered by a high public official and social worker Mahbub Alam Chashi, the movement was formally launched on 24 September 1975 under the patronage of the Bangladesh government. The main thrust of its activities was geared towards increasing food production and income generation. The need and importance of moral and ethical values and qualities were also emphasised. The idea and visions of the movement drew substantially from a number of earlier rural development initiatives. In 1967, similar ideas were explored in a participatory project at Gumai in Rangunia, Chittagong

6. The Sarvodaya Shramadana Movement is a selfgovernance movement in Sri Lanka, which provides comprehensive 
development and conflict resolution programs to villages. It is also the largest indigenous organization working in reconstruction from the tsunami caused by the 2004 Indian Ocean earthquake. Founded in 1958 by Dr A. T. Ariyaratne when he took "forty high school students and twelve teachers from Nalanda College Colombo on "an educational experiment" to an outcaste village, Kathaluwa, and helped the villagers fix it up. It is based on Buddhist and Gandhian principles, including sarvodaya from which it got the name and swaraj (self-governance). The word «shramadana" means "a gift of labor

Acharya, Keshav K. (ORCID: 0000-0003-3295-0003) $\mathrm{PhD}$ is currently working in German Development Cooperation project in Kathmandu Nepal. He holds Phd in Local Governance and Service Delivery System in Nepal from the University of New England, Australia. His main interest areas are governance, institutional Capacity Development, service delivery, Disaster management, Peacebuilding, and community development. Further, he completed MSc in Regional Planning from the Asian Institute of Technology Thailand. Dr. Acharya as a Local Governance expert has worked in different positions and projects of German Development Cooperation, UNDP, and other development projects (Nepal, Thailand, and Australia) for more than 20 years. Additionally, he persuaded the number of research and development projects in the area of capacity gap assessment of central and local government bodies, impact assessment of community development, and formulation of local government strategic plans and disaster plans. He has written some books, articles and research papers on governance, peacebuilding and service delivery, which are published in peer-reviewed international journals and book chapters. Email: keshavkacharya@gmail.com 